\title{
Cytoflowmetric Analysis of Binding Pattern and A New Binding Kinetic Constant for an Enterovirus and Receptor
}

\author{
MASANOBU CHINAMI AND MASAHISA SHINGU \\ Department of Virology, Kurume University School of Medicine, Kurume, 830 Japan
}

Received for publication February 23, 1985

\begin{abstract}
Summary: A bovine enterovirus (MZ-468) was adsorbed to Sarcoma-180 cells at $4^{\circ} \mathrm{C}$. The cells were reacted with FITC-labeled IgG antibody for the virus and were studied with a laser fluorescence cytoflowmeter. From the histograms, binding-saturation of receptors was observed and the dissociation constant (Kd) was estimated. A new binding rate constant was deduced from the change of the ratio of virus-adsorbed cells against time and virus concentration. The constant has a dimensions of $\left(\mathrm{cm}^{3} / \mathrm{min} \cdot\right.$ receptor-site) and probably represents the receptor class on a cell with the highest rate constant.
\end{abstract}

Key words: virus receptor-binding kinetic constant-dissociation constant - binding saturation - enterovirus

\section{Introduction}

The host range of a virus depends on the existence of the specific receptors on the cell membrane (McLaren et al. 1959, Crowell and Landau, 1983). The specificity depends on the affinity of a virus for the receptor at an early stage of infection. Most of the research on binding patterns and kinetic constants of a virus and its receptors have utilized radioisotope-labeling of virus particles (Schlegel et al. 1982; Huggins et al. 1983) by determining radioactivity of labeled virus. The virus-labeling method for studying virus receptors gives the amount of bound-virus to an average cell but not the amount bound to individual cells, from the virus-side. Cytoflowmetry was employed in this study to give the amount of virus bound to individual cells and the amount of virus-bound cells at the same time (Shapiro and Volsky, 1983). By using the cytoflowmeter, a unique analysis of the virus receptor can be performed without radioisotope from cell-side.

\section{Methods}

\section{Cell and Virus}

Sarcoma-180 cells were spinner-cultured in Eagle's Essential Medium (MEM, GIBCO) containing $10 \%$ calf serum. A bovine enterovirus (MZ-468) was isolated (Shingu, 1976) and propagated in monolayered HeLa cells at a multiplicity of infection (m. o. i.) of 1.0. The cells were frozen and thawed twice and the cellular debris was removed by centrifugation at $10,000 \times \mathrm{g}$ for $20 \mathrm{~min}$. The supernatant was ultracentrifuged twice at $1.4 \times 10^{5} \mathrm{~g}$ for $1 \mathrm{hr}$ with a Hitachi RP50. The pellet was resuspended in a $\mathrm{CsCl}$ saline solution (refractive index, 1.367) and was ultracentrifuged in the angle rotor (Hitachi-RP-50) at $40,000 \mathrm{rpm}$ for 18 hrs. Peak fractions monitored at $260 \mathrm{~nm}$ by the spectrophotometer (Hitachi-220) were collected and dialized twice against one 1 of $0.02 \mathrm{M}$ HEPES buffer ( $\mathrm{pH} \mathrm{7.0)}$ for $24 \mathrm{hrs}$ (OD $280 / \mathrm{OD} 260 ; 1.47$ ). The virus titration was performed on monolayers of HeLa cells. 


\section{Immunization and purification of IgG}

A rabbit was given a subcutaneous injection of $1 \mathrm{ml}$ of the virus purified with $\mathrm{CsCl}$ (infectious titer; $2 \times 10^{8} \mathrm{pfu} / \mathrm{ml}$ ) containing $20 \%$ complete Freund's adjuvant (Difco Labo.). The same virus solution without the adjuvant was injected intravenously three times at three day intervals. After a three week interval without an injection, a single injection was administered. Twenty $\mathrm{ml}$ of the blood were collected and centrifuged at $2500 \mathrm{rpm}$ for 10 min at room temperature. Ten $\mathrm{ml}$ of the serum were separated and heat-inactivated at $56^{\circ} \mathrm{C}$ for $30 \mathrm{~min}$. The serum was dialy zed against one 1 of $0.05 \mathrm{M}$ Tris- $\mathrm{HCl}$ buffer $(\mathrm{pH} \mathrm{8.0)}$ and was applied on $1.6 \mathrm{~g}$ (column; $1 \times 6 \mathrm{~cm}$ ) of protein-A-sepharose CL-4B (Pharmacia fine chemicals) which had been equilibrated with the same buffer. Ten $\mathrm{ml}$ of the IgG fraction were obtained by eluting at room temperature with $0.05 \mathrm{M}$ acetic buffer ( $\mathrm{pH} \mathrm{4.3)} \mathrm{monitoring}$ at $280 \mathrm{~nm}$ with the spectrophotometer (Hitachi-220) (Goding, 1976). The IgG was confirmed by the Ouchterlony's immunodiffusion method.

\section{FITC-labeling of IgG}

Ten $\mathrm{ml}$ of the IgG fraction were dialyzed against $0.05 \mathrm{M}$ carbonate and bicarbonate buffer (CBB, $\mathrm{pH} \mathrm{9.2)} \mathrm{for} 4 \mathrm{hrs}$ at $4^{\circ} \mathrm{C}$. The fraction was dialyzed again against $0.6 \ell$ of $0.05 \mathrm{M} \mathrm{CBB}$ containing 100 $\mu \mathrm{g} / \mathrm{ml}$ of fluorescein isothiocyanate (FITC, Dotite) for $17 \mathrm{hrs}$ at $4{ }^{\circ} \mathrm{C}$. The reaction was stopped by dialysis against $0.02 \mathrm{M}$ of phosphate buffer ( $\mathrm{pH}$ 6.6) and was applied on the DEAE-cellulose column $(1 \times 10$ $\mathrm{cm}$ ) which had been equilibrated with the same buffer. The conjugate was fractionated by $0.0175 \mathrm{M}$ PBS containing $\mathrm{NaCl}$ (from 0 to $1 \mathrm{M}$ ) (Goding, 1976). The fractions with $F / P$ rations of $1.5-2.0$ were collected (Brighton and Jhonson, 1971). The neutralizing titer of the conjugate was $1: 180$, as ssessed by the $50 \%$ plaque re- duction method.

\section{Absorption of FITC-labeled IgG by cells}

HeLa cells that were monolayer-cultured in two bottles $(10 \times 15 \mathrm{~cm})$ were detached physically with a rubber policeman and suspended in saline. The suspension was centrifuged at 1,000 rpm for $6 \mathrm{~min}$ and the cell pellet was obtained. The pellet was resuspended in the solution of FITC-labeled IgG and incubated for $6 \mathrm{hrs}$ at room temperature. This procedure was repeated once.

\section{Adsorption of virus and cytoflowmetry}

The following experiments were executed at $4^{\circ} \mathrm{C}$ except the measurement with the cytoflowmeter.

(1) Twelve $2 \mathrm{ml}$ samples of the cell suspension (Sarcoma-180 cells $5 \times 10^{3}$ cells/ $\mathrm{ml}$ ) were centrifuged at $1000 \mathrm{rpm}$ for 6 min. One-half $\mathrm{ml}$ of $1 / 2$ diluted virus (original; $2 \times 10^{9} \mathrm{pfu} / \mathrm{ml}$ ) in $0.02 \mathrm{M}$ HEPES buffer ( $\mathrm{pH}$ 7.0, Dotite) was added to eleven samples and the same buffer was added to the other sample without virus for the control. After $2 \mathrm{hrs}$ adsorption all the samples were washed twice with $3 \mathrm{ml}$ saline. Forty $\mu \mathrm{l}$ of FITC-labeled IgG (0.2 $\mathrm{mg} / \mathrm{ml}$ protein by O.D. ) were added to the cell pellets and they were incubated for $30 \mathrm{~min}$ and then washed with saline. The cells were resuspended in $0.02 \mathrm{M}$ HEPES buffer and measured by the cytoflowmeter (Orthospectrum III) with a green filter, gain 430 (5).

(2) Five $\mathrm{ml}$ of the cells $\left(5 \times 10^{3}\right.$ cells/ $\mathrm{ml}$ ) were washed twice in $0.02 \mathrm{M}$ HEPES buffer and the virus (infectious titer; $2 \times$ $10^{9} \mathrm{pfu} / \mathrm{ml}$, ) in the same buffer was added to the pellets. At $0,0.5,1,2,4,10,16$ min, $0.5 \mathrm{ml}$ of the cell suspension was extracted and washed twice in $1.5 \mathrm{ml}$ of the buffer. The samples were then reacted with the FITC-labeled IgG, as above, and measured by the cytoflowmeter, under the same conditions as above. 
(3) Two $\mathrm{ml}$ of the cells $\left(5 \times 10^{3}\right.$ cells $\left./ \mathrm{ml}\right)$ in $20 \mathrm{mM}$ HEPES buffer were pipetted into 8 cornical test tubes and washed twice in the buffer. One-half $\mathrm{ml}$ aliquots of the various concentrations of virus in the same buffer $\left(0,0.2,0.4,1,2,4,7,20 \times 10^{8}\right.$ $\mathrm{pfu} / \mathrm{ml}$ ) were added to the cell pellets and the preparations were incubated for 30 min. After washing, the cells were reacted with FITC-labeled IgG and measured by the cytoflowmeter, as described above.

\section{Results}

\section{Study of virus binding pattern}

To study the binding pattern of an enterovirus (MZ-468) to Sarcoma-180 cells, the cells were adsorbed to the virus at $4^{\circ} \mathrm{C}$ for two hours and were measured by the laser fluorescence cytoflowmeter. In the histograms in Fig. 1, the ordinate represents the relative number of cells on a linear scale and the abscissa represents
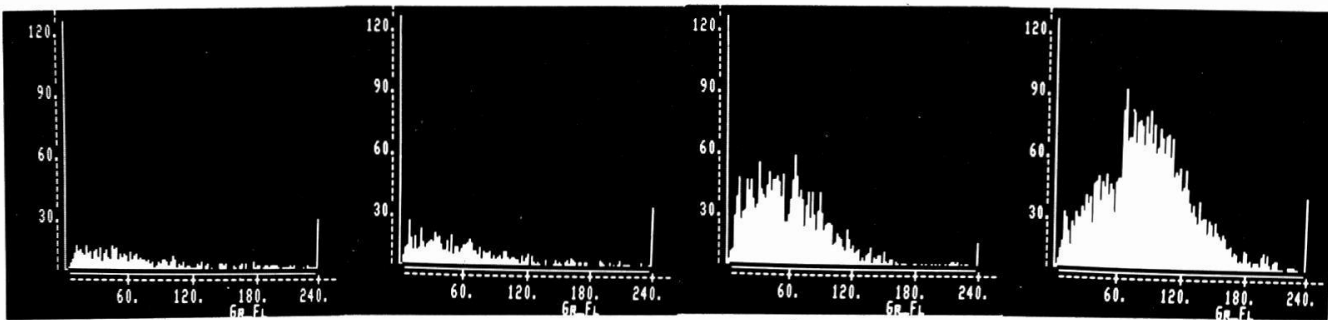

2
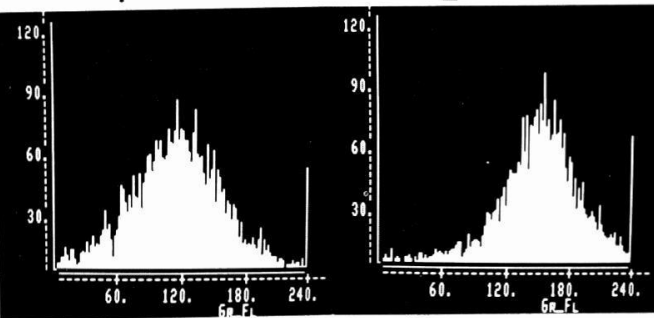

3

4
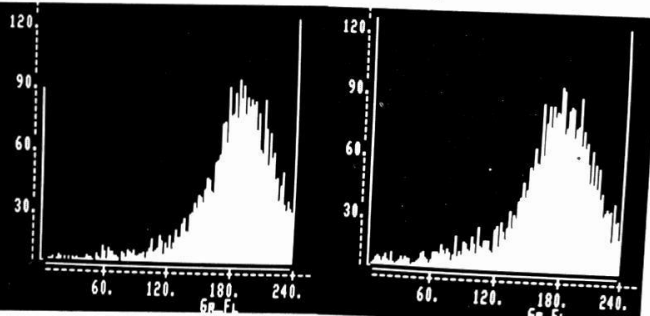

5

6

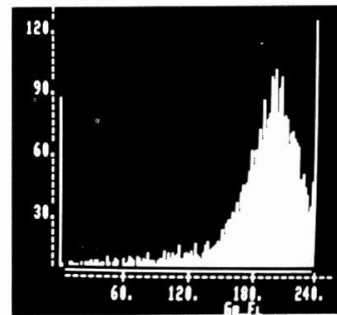

9

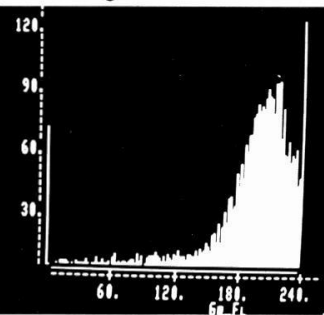

10

7

8

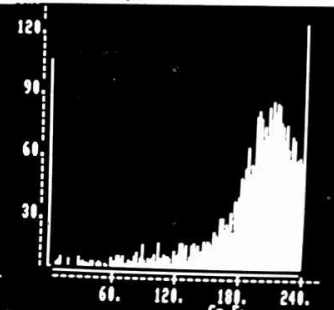

11

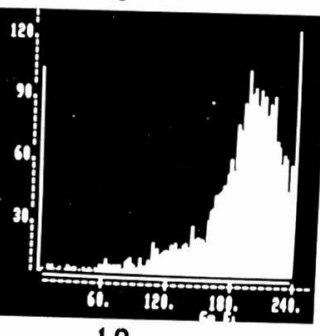

12

Fig. 1. Virus binding patterns to Sarcoma-180 cells determined by fluorescence cytoflowmetry.

Virus (MZ-468) at various concentrations was adsorbed to Sarcoma-180 cells at $4{ }^{\circ} \mathrm{C}$, reacted with FITC-labeled IgG and measured by the cytoflowmeter, as des cribed in the methods. The vertical bars indicate the relative cell numbers on a linear scale and the abscissa is the relative intensity of fluorescence on a $\log$ scale. 1-control, 2, 3, $4 \cdots \cdots 9,10,11-(1 / 2)^{10},(1 / 2)^{9},(1 / 2)^{8} \cdots \cdots(1 / 2)^{2},(1 / 2)^{1}$, $(1 / 2)^{0}$ of $2 \times 10^{9} \mathrm{pfu} / \mathrm{ml}$. 
the relative intensity of fluorescence on a log scale. The fluorescence intensity should be related to the amount of the virus bound to cell membrane. Each panel in Fig. 1 corresponds to a specific virus concentration, ranging from $(1 / 2)^{10}$ to $(1 / 2)^{0}$ of $2 \times 10^{9} \mathrm{pfu} / \mathrm{ml}$. Number 1 is a control without the virus. A typical normal distribution is found in panel 5 and 6 . At concentrations greater than $2.5 \times 10^{8} \mathrm{pfu} /$ $\mathrm{ml}$ (9 in Fig. 1), there was no further shift of the mode to the right.

Although the whole IgG fractions were used as the antibody, instead of Fab fragments, no significant aggregation of cells was observed. These experiments were performed under antibody excess.

\section{Analysis of virus-binding equilibrium}

Binding equilibration between the cells and viruses was achieved by adsorption at $4^{\circ} \mathrm{C}$ for more than two hours. The equiblium can be expressed as follows.

$$
\mathrm{C}+\mathrm{V} \rightleftarrows \mathrm{C}-\mathrm{V}
$$

(C, virus-free cell; $\mathrm{V}$, virus;

$\mathrm{C}-\mathrm{V}$, virus-bound cell)

The virus-concentrations were much greater than the cell-concentrations $(\mathrm{V} \gg \mathrm{C})$, thus $\mathrm{V}$ can be substituted with the initial virus concentration (Vo). The dissociation constant for the relationship can be expressed as follows.

$$
\mathrm{Kd}=[\mathrm{C}] \cdot[\mathrm{Vo}] /[\mathrm{C}-\mathrm{V}]
$$

The cytoflowmeter gives us a negative ratio; $r$, the number of virus free-cells/ the number of total cells. The ratio is expressed as follows.

$$
\mathrm{r}=[\mathrm{C}] /[\mathrm{C}]+[\mathrm{C}-\mathrm{V}]
$$

From equations (2) and (3),

$$
1 / \mathrm{r}=1+(1 / \mathrm{Kd}) \cdot \mathrm{Vo}
$$

From the experiments on the virus binding patterns, previously described, $1 / \mathrm{r}$ was plotted against Vo (Fig. 2). Two slopes are present. From the slopes, the Kds

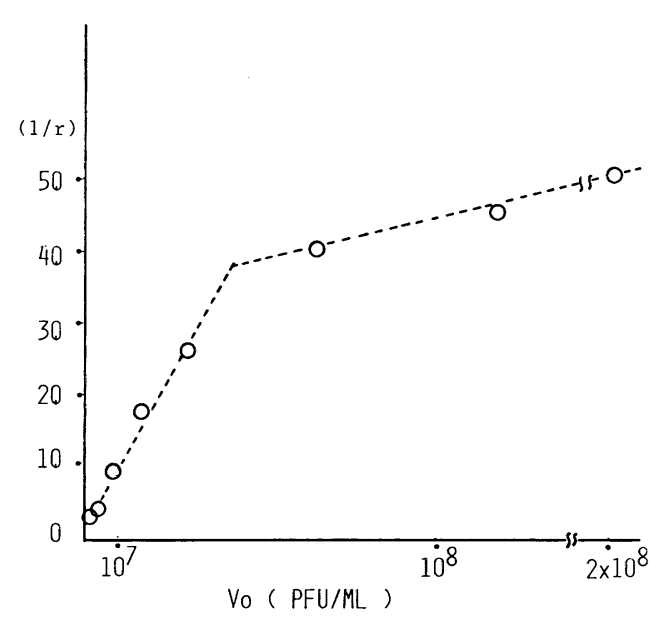

Fig. 2. Plot of $1 / \mathrm{r}$ against the initial virus concentration for the experiment in Fig. 1.

The negative ratios ( $r$ ) were obtained from the cytoflowmeter and the values were derived from the equation 3 in the text. The data correspond to the results in Fig. 1.

were calculated as $2.2 \mathrm{pM}$ and $0.1 \mathrm{nM}$, assuming $1 \mathrm{pfu}$ equals 1000 virus particles, as estimated from optical density (Rueckert, 1976; Schwerdt and Schaffer, 1955).

\section{Induction of an inital rate constant from receptor-side}

Two series of experiments were performed to determine the binding rate constant by using a cytoflowmeter. The duration of adsorption was varied at a constant virus-concentration or virus-concentration was varied at a constant duration of adsorption. In both experiments the negative ratios ( $r$ ) decreased with time or with virus-concentration, generating hyperbolic curves (Fig. 3, 4). The rate of the forward reaction in the above equilibrium (equation 1) can be measured by the change in concentration of virus-free cells with time, $t$, early in the experiment before the concentration of virus-bound cells become significant (Incardona, 1983). 
The foward reaction is expressed as follows.

$$
\mathrm{C}+\mathrm{V} \rightarrow \mathrm{C}-\mathrm{V}
$$

The decreasing concentration of virus-free cells can be expressed as follows.

$$
\begin{aligned}
\mathrm{dC} / \mathrm{dt}=-\mathrm{kc} \cdot \mathrm{C} \cdot \mathrm{V} \\
\mathrm{V} \gg \mathrm{C} \cdots \cdots \cdots \cdots \cdots \cdot \mathrm{V}=\mathrm{Vo} \\
\mathrm{dC} / \mathrm{dt}=-\mathrm{kc} \cdot \mathrm{C} \cdot \mathrm{Vo}
\end{aligned}
$$

The above equation can be solved,

$\log \mathrm{C}=-\mathrm{kc} \cdot \mathrm{Vo} \cdot \mathrm{t}+$ constant

$\mathrm{t}=0 \cdots \cdots \mathrm{C}=\mathrm{Co}(\mathrm{Co}$; initial cell-concentration)

$$
\therefore \mathrm{C} / \mathrm{Co}=\exp (-\mathrm{kc} \cdot \mathrm{Vo} \cdot \mathrm{t})
$$

$\mathrm{C} / \mathrm{Co}$ is the negative ratio ( $\mathrm{r}$ ). This equation was optimized by including parameters, $a$ and $b$, arising from the non-specific reaction of fluorochrome and the error of measurement. The final equation was expressed as:

$\mathrm{r}=(\mathrm{a}-\mathrm{b}) \exp (-\mathrm{kc} \cdot \mathrm{Vo} \cdot \mathrm{t})+\mathrm{b}(\mathrm{kc}$, initial rate constant; $t$, time; $a, b$, parameters)

The two series of experimental data were curve-fitted to the above equation. The parameter a was the negative ratio of the virus free sample. According to a computor program (the program was provided by Dr. K. Harada of the Computor Center of Kurume Univ.), $\mathrm{kc}$ and $\mathrm{b}$ were calculated by inputting $r$, $a$, and $t$ or Vo. The value of $\mathrm{kc}$ for Sarcoma-180 cells were $3 \times 10^{-10}$ and $3 \times 10^{-11} \mathrm{~cm} / \mathrm{min} \cdot \mathrm{pfu}$, respectively with time and virus-concentration as the variable functions. The kc value was roughly estimated to be $10^{-13 \sim-14} \mathrm{~cm}^{3} / \mathrm{min} \cdot$ virus - part cle by assuming that 1 pfu equals 1000 particles, as described above.

\section{Discussion}

The histograms in Fig. 1 can be interpreted as the distributions of cells which bound varing amounts of virus on the

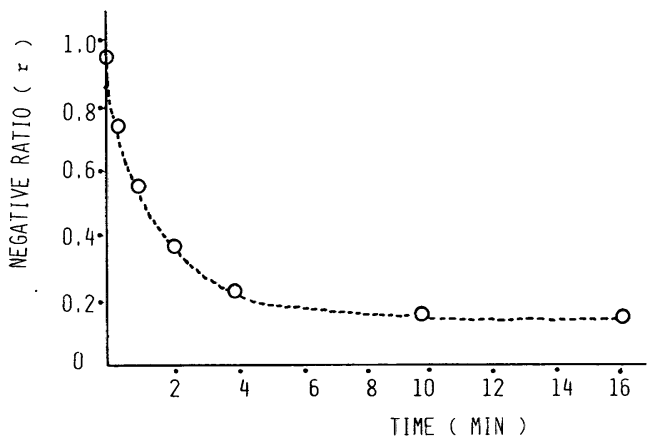

Fig. 3. Decrease of the negative ratio with time at a constant virus concentration.

Sarcoma-180 cells adsorbed in $2 \times 10^{8}$ $\mathrm{pfu} / \mathrm{ml}$ at $4^{\circ} \mathrm{C}$ and $0.5 \mathrm{ml}$ of the cell suspension were extracted at each point in time. After reacting with FITC-labeled IgG, the samples were measured by the cytoflowmeter.

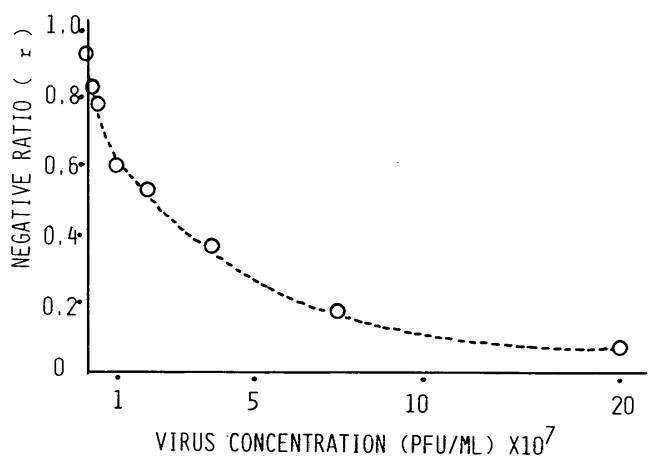

Fig. 4. Change of the negative ratio with virus concentration at a constant duration of adsorption.

Sarcoma-180 cells adsorbed viruses at various concentrations at $4^{\circ} \mathrm{C}$ for thirty min. After reacting with FITC-labeled IgG, the samples were measured by the cytoflowmeter.

plasma membrane. Shifting of the histogram to the right on an abscissa of virus concentration means an increased amount of virus has been bound to individual cells. The cells at the mode of histogram are considered to be the typical cell group with virus-binding activity. When there 
is no further sfifting (panel 9 in Fig. 1), binding sites in this cell line are probably saturated. At saturation the diversions of the histograms seemed to depend on the relationship between virus and cells. Data from other cell lines have different diversions (not shown).

Plotting the binding equilibrium for $1 / \mathrm{r}$ vs input-virus concentration yields the dissociation constant (Kd). Two Kds can be obtained from the slopes in Fig. 2 meaning there are two classes of receptors on the cells, high affinity and low affinity receptors. This is compatible with the data from Shlegel et al. (1982), in which Kds of Vero cells to Vesicular Stomatitis virus were analyzed by a Scatchard plot with a computor program. The present analysis is simpler, easier to calculate, and does not involve a radioisotope. An initial rate constant, $\mathrm{K}_{\mathrm{R}}$, presented by Lonberg-Holm et al. (1976), describes the affinity of a cell to a virus (Morishma et al. 1983). The $\mathrm{K}_{\mathrm{R}}$ has the dimensions of $\mathrm{cm}^{3} / \mathrm{min} \cdot$ cell which describes the average rate for all receptors on a cell, but not the rate of an individual receptor. On the other hand, $\mathrm{kc}$ has different dimensions of $\mathrm{cm}^{3} / \mathrm{min} \cdot$ virusparticle and describes the rate for a single virus. As a single virus-particle is thought to bind to a single receptor, the dimensions of $\mathrm{kc}$ can be converted to $\mathrm{cm}^{3} / \mathrm{min} \cdot$ receptor-site. As schematically shown in Fig. 5, $\mathrm{K}_{\mathrm{R}}$ represents the binding velocity of a virus to any sites on the cell, while "kc" represents the velocity to the single virus receptor. The ratio of $K_{R}$ and "kc" (site/ cell) represents the number of equivalent receptor sites for a cell. The relationship of the two constants is considered to be expressed as follows.

$\mathrm{K}_{\mathrm{R}}=\mathrm{n} \cdot \mathrm{kc}$ ( $\mathrm{n}, \mathrm{kc}$; the number and rate constant of receptors with a high rate constant)

The functions derived by Adam and Delbruck (1968) and Berg and Percell (1977)

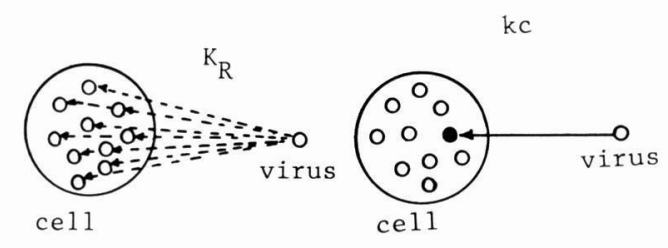

Fig. 5. Schematic representation of the difference between $K_{R}$ and $k c . K_{R}$ represents the highest rate constant at which a virus particle can bind to any receptors on the cell membrane.

" $k c$ " represents a rate constantf for binding of which a single virus particle binds to the virus receptor with the high rate constant.

also expressed the relationship between the number of receptors per cell and the binding rate constant, but they have dif ferent dimensions due to the method of derivation of the original function.

The cytoflowmeter can theoretically detect a cell which binds a single virus particle in our system. When a cell binds a single virus particle the positive ratio increases. Therefore " $k c$ " can be interpreted to represent the highest rate constant among all the receptor classes on a cell.

When considering the specificity or susceptibility of the organ in vivo, the efficiency of the infection under low multiplicity of infection (m. o. i.) must be taken into account, because a single infectious virus can be adequate to infect a cell. Thus a high rate constant for the receptors on a cell should be taken into account when susceptibility of a cell is discussed. The measurement of " $\mathrm{kc}$ " is useful to evaluate the susceptibility of a cell. In conclusion, cytoflowmetrical analysis of receptors contributes to the analysis of receptor classes and to the estimation of the binding rate constant for susceptibility of a cell by virus. This method will be applied to other types of receptors from cell-or receptor-side. 
Acknowledgment: The authors are extremely grateful to Prof. T. Tanaka of the Faculty of Science, Kyushu Univ. for critical discussion and Dr. Karl Lonberg-Holm for his valuable comments. They also thank Prof. M. Yokoyama of Kurume Univ. for the use of the cytoflowmeter and Mrs M. Ohara for correcting the manuscripts.

\section{References}

Adam, G. and Delburuck, M. (1968). Reduction of dimensionality in biological diffusion process. In Structual Chemistry and Molecular Biology. ed. Rich, A. and Davidson, N. pp. 198-215 San Francisco: Freeman

Berg, H.C. and Percell, E.M. (1977). Physics of chemoreception. Biophys. J. 20,193-219.

Brighton, W.D. and Johnson, E. A. (1971). Conjugation of parameters determined with FITC. Ann. New York Acad. Sci. 177, 501505.

Crowell, R. and Landau, B. J. (1975). In Comprehensive Virology ed. Fraenkel Conrat, H. and Wagner, R.R. vol. 18, pp 1-33, New York: Plenum.

Goding, J.W. (1976). Conjugation of antibodies with fluorochromes: Modifications to the standard methods. J. Immuno. Methods, 13, 215-226.

Huggins, J. W., Jahrling, P. B., Rill, W. and LiNDEN, C.D. (1983). Characterization of the binding of the TC-83 strain of Venezuelan Equine Encephalomyelitis Virus to BW-J-M, a mouse macrophage-like cell line. J. Gen.
Virol. 64, 149-157.

InCARDONA, N.L. (1983). Binding of virus and ligands to cells: Effect of receptor density. J. Theor. Biol, 104, 693-699.

Lonberg-Holm, K. and Whiteley, N.M. (1976). Physical and metabolic requirements for early interaction of poliovirus and human rhinovirus with HeLa cells. J. Virol. 19, 857-870.

McLaren, L. C., Holland, J. J. and Syverton, J. T. (1959). The mamalian cell-virus relationship. I. Attachment of poliovirus to cultured cells of primate and nonprimate origin. J. Exp. Med. 109, 475-485.

Morishima, T., McClintock, P. R., Aulakh, L.B. and Notkins, A.L. (1983). Genomic and receptor attachment differences between Mengovirus and Encephalomyocarditis virus. Virology, $122,461-465$.

RUECKERT, R.R. (1976). On the structure and morphogenesis of picornavirus in Comprehensive Virology, ed. Fraenkel-Conrat, $\mathrm{H}$. vol. 6, pp 131-213, New York: Plenum.

Schlegel, R., Willingham, M. C. and Pastan, I. H. (1982). Saturable binding sites for Vesicular Stomatitis Virus on the Surface of Vero cells. J. Virology, 43, 871-875.

Schwerdt, C.E. and Schaffer, F. L. (1955). Poliomyelitis virus and methods for its study. Ann. New York Acad. Sci. 61, 740-753.

Shapiro, I. M. and Volsky, D. J. (1983). Infection of normal human epitherial cells by $\mathrm{Eb}$ stein-Bar virus. Science, 219, 1225-1228.

Shingu, M. (1976). Oncolytic bovine enteiovirus in the treatment of human tumors. Nishinihon-Hinyokika, 38, 1-6 (in Japanes) 